DOI: https://doi.org/10.31933/dijms.v2i1 Received: 14 July 2020, Revised: 15 August 2020, Publish: 24 September 2020

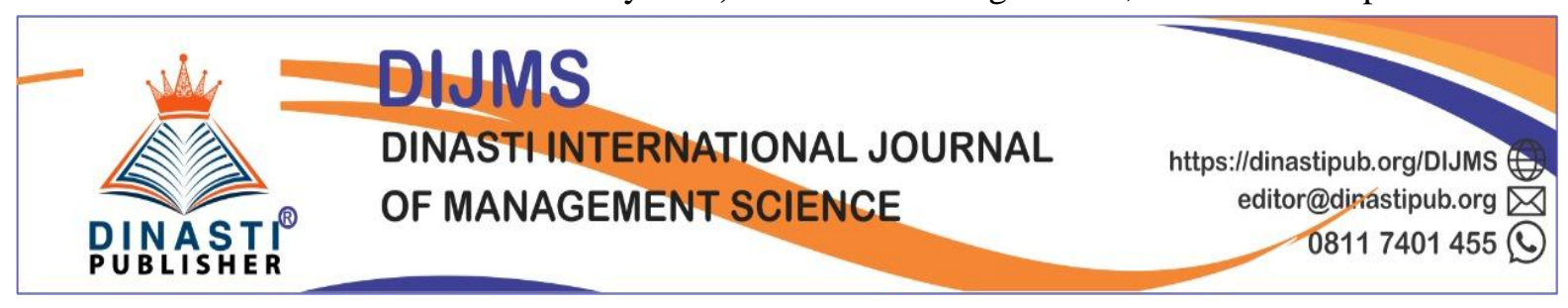

\title{
RELATED IMPACT FROM SERVICE QUALITY AND PRODUCT QUALITY TOWARDS CUSTOMER SATISFACTION AS WELL AS ITS IMPLICATIONS TO CUSTOMER LOYALTY AT PT. CIANJUR ARTHA MAKMUR
}

\author{
Dwian Adi Dharmawan'), Arifin Sitio ${ }^{2)}$ \\ ${ }^{1)}$ Master of Management Student in Mercu Buana University, Jakarta, Indonesia, \\ wiyandharmawan@gmail.com \\ 2) Lecturer of Postgraduate Program in Mercu Buana University, Jakarta, Indonesia, \\ arifin.sitio@mercubuana.ac.id
}

\section{Corresponding Author: First Author}

Abstract: This research aims to find out those influence from Service Quality, and Product Quality towards Customer Satisfaction and its Implications to Customer Loyalty at PT. Cianjur Artha Makmur. This type of research were catagorized as descriptive analytics research. While population were customers from PT Cianjur Artha Makmur (CAM) totalling of 543 customers according to 2018 company's internal data. These research used Slovin formula to estimates these sample size needed and it obtained 100 respondents. The analysis technique used path analysis through SPSS version 23. The results from this research was indicate that (1) Service Quality has huge impact to Customer Satisfaction (2) Product Quality has significant influence over Customer Satisfaction (3) Service Quality has marked effect to Customer Loyalty (4) Product Quality has undefinable affects towards Customer Loyalty and (5) Customer Satisfaction has huge impact on Customer Loyalty.

Keywords: Service Quality, Product Quality, Customer Satisfaction, Customer Loyalty.

\section{INTRODUCTION}

The development of historical data and projections results show that world beef market and Indonesia continue to increase. However, the main problems faced in future are the growth rate of consumption and prices that higher than growth of cattle population and beef production both in world and Indonesia. Data from Ministry of Agriculture states tells that total national beef production in 2018 was estimated around 403,668 tons with total demand of 663,290 tons. So those fulfillment of beef needs on community is only $60.9 \%$ which could be fulfilled by local cattle farmers (Kementan, 2018).

Animal products contribute $17 \%$ of global kilocalorie consumption and $33 \%$ of global protein consumption (FAOSTAT 2008; Daryanto, 2010). Viewed from meat production which traded on global market gives an illustrated whereas sequently was poultry, beef, pork, and lamb. Huge number of beef needs in Indonesia creates challenge for livestock companies 
to continue to fill the needs of beef in country both for modern markets and also traditional markets.

Table 1. Growth of Livestock in Indonesia

\begin{tabular}{|c|c|c|c|c|c|c|c|c|c|c|c|c|}
\hline \multirow[t]{2}{*}{ No. } & \multirow[t]{2}{*}{ Jenis } & \multicolumn{9}{|c|}{ Tahun } & \multirow[b]{2}{*}{ Rerata } & \multirow{2}{*}{$\begin{array}{l}\text { Trend } \\
(\% / \text { th) }\end{array}$} \\
\hline & & 2004 & 2005 & 2006 & 2007 & 2008 & 2009 & 2010 & 2011 & 2012 & & \\
\hline & Daging & 2020.4 & 1817.0 & 2062.9 & 2069.5 & 2136.6 & 2204.9 & 2366.2 & 2554.2 & 2690.9 & 2213.6 & 3.85 \\
\hline 1 & $\begin{array}{l}\text { Sapi } \\
\text { potong }\end{array}$ & 447.6 & 358.7 & 395.8 & 339.5 & 392.5 & 409.3 & 436.5 & 485.3 & 505.5 & 419.0 & 2.27 \\
\hline 2 & Kerbau & 40.2 & 38.1 & 43.9 & 41.8 & 39.0 & 34.6 & 35.9 & 35.3 & 35.3 & 38.2 & -1.33 \\
\hline 3 & Kambing & 57.1 & 50.6 & 65.0 & 63.6 & $\begin{array}{ll}66.0 \\
\end{array}$ & 73.8 & 68.8 & $\begin{array}{l}66.3 \\
\end{array}$ & 68.6 & 64.4 & 2.95 \\
\hline 4 & Domba & 66.1 & 47.3 & 75.2 & 56.9 & 47.0 & 54.3 & 44.9 & 46.8 & 46.5 & 53.9 & -1.17 \\
\hline 5 & Babi & 194.7 & 173.7 & 196.0 & 225.9 & 209.8 & 200.1 & 212.0 & 224.8 & 234.7 & 208.0 & 2.74 \\
\hline 6 & Kuda & 1.6 & 1.6 & 2.3 & 2.0 & 1.8 & 1.8 & 2.0 & 2.2 & 2.2 & 1.9 & 5.23 \\
\hline 7 & $\begin{array}{l}\text { Ayam } \\
\text { Buras }\end{array}$ & 296.4 & 301.4 & 341.3 & 294.9 & 273.5 & 247.7 & 267.6 & 264.8 & 274.2 & 284.6 & -0.60 \\
\hline 8 & $\begin{array}{l}\text { Ayam Ras } \\
\text { Petelur }\end{array}$ & 48.4 & 45.2 & 57.6 & 58.2 & 57.3 & 55.1 & 57.7 & 62.1 & 63.7 & 56.1 & 3.92 \\
\hline 9 & $\begin{array}{l}\text { Ayam Ras } \\
\text { Pedaging }\end{array}$ & 846.1 & 779.1 & 861.3 & 942.8 & 1018.7 & 1101.8 & 1214.3 & 1337.9 & 1428.8 & 1059.0 & 6.94 \\
\hline 10 & Itik & 22.2 & 21.4 & 24.5 & 44.1 & 31.0 & 25.8 & 26.0 & 28.2 & 30.8 & 28.2 & 7.86 \\
\hline 11 & Kelinci & - & - & - & - & - & 0.1 & 0.1 & 0.2 & 0.2 & 0.2 & - \\
\hline 12 & $\begin{array}{l}\text { Burung } \\
\text { puyuh }\end{array}$ & - & - & - & - & - & 0.2 & -1 & 0.1 & 0.2 & 0.2 & - \\
\hline 13 & Merpati & - & - & - & - & -1 & 0.3 & \begin{tabular}{l|l|}
0.4 & \\
\end{tabular} & \begin{tabular}{l|l}
0.1 & \\
\end{tabular} & 0.3 & 0.3 & - \\
\hline
\end{tabular}

Sumber : StatistikPeternakan, Tahun 2008 dan 2012

PT. Cianjur Artha Makmur is one of companies which engaged in beef trade industry. PT Cianjur Artha Makmur has committed to supporting the national meat selfsufficiency program. To attained this program, PT Cianjur Artha Makmur was established a slaughterhouse which consist of slaughtering rooms, boning rooms, aging rooms, chill rooms, blast rooms and cold storage and fully supported by halal workers from MUI to make RedBeef a meat product superior cattle with high quality, safe and halal for public consumption.

Comprehension of consumer behavior is an important duty for marketers. Marketers try to understand those behavior so they could offer greater satisfaction to consumers. In an effort to maintain the surviving of its business in Indonesia, PT Cianjur Artha Makmur continues to strive and improve performance by increasing customer satisfaction. To determined the main factors / triggers of purchase satisfaction and decision, these researchers was conducted a Pre-research by interviewing 45 customers of PT Cianjur Artha Makmur. From these pre-research outcome those respondents was stated that service quality and products quality which current offered not exceed those expectations from consumers.

Table 2. Pre-Research Results

\begin{tabular}{|c|c|c|c|c|c|c|c|}
\hline \multirow{2}{*}{ No } & \multirow{2}{*}{ Statement/Question } & \multirow[t]{2}{*}{ Total } & \multicolumn{4}{|c|}{ Number of People } & \multirow{2}{*}{$\begin{array}{c}\text { Percentage } \\
(\%)\end{array}$} \\
\hline & & & Yes & $\%$ & Not & $\%$ & \\
\hline 1 & PT Cianjur Artha Makmur has a good level of service & 45 & 19 & $42 \%$ & 26 & $58 \%$ & $100 \%$ \\
\hline 2 & Freshness from PT Cianjur Artha Makmur's products has been proven & 45 & 21 & $47 \%$ & 24 & $53 \%$ & $100 \%$ \\
\hline 3 & $\begin{array}{l}\text { PT Cianjur Artha Makmur has never received complaints from } \\
\text { customers regarding the product }\end{array}$ & 45 & 17 & $38 \%$ & 28 & $63 \%$ & $100 \%$ \\
\hline
\end{tabular}


Beside that, there has difference results from prior research (gap research). ICA and Forex has huge relationship between service quality and customer satisfaction; but Umeå University does not have a significant relationship between service quality and customer satisfaction. Meanwhile the group results show that: "response", empathy "and" reliability "are significantly related to service quality; "Reliability" and "empathy" are significantly related to customer satisfaction but "responsiveness" is not significantly related to customer satisfaction; meanwhile service quality is significantly related to customer satisfaction (Jenet, 2011).

From these pre-research outcomes which shown above also gap research in prior research, in this case the writer needs to do deeper research to be able to prove whether there would be huge and mutual influence both Service Quality and Product Quality to Customer Satisfaction aswell as its implications on Customer loyalty. Link to that matters, the authors turn up this matters into research with title "Related impact from Service Quality and Product Quality towards Customer Satisfaction as well as Its implications to Customer Loyalty at PT. Cianjur Artha Makmur".

\section{THEORETICAL REVIEW}

\section{Service Quality}

Based on Kotler and Armstrong in Pradita and Sitio (2020)it said that service quality is overall characteristics from a product or service which influences its ability to fill both explicit and implicit needs. Whereas Alma in Prianggoro and Sitio (2019) was defines services as a series of activities which invisible (inaccessible) that occur as an interactions outcome between consumers and employees or other things that provided by service provider companies who intended to solve consumer problems /customer.

\section{Product Quality}

According to American Society for Quality Control in Desyana and Basri (2019) explained that product quality is overall characteristics and nature of a product or service which has an affects to its ability to satisfy or implied needs. Meanwhile Cannon, et. al. Rahman and Sitio (2019) defined that product quality is an ability from product to meet with customer needs or desires. Thus level of product quality is directly proportional to level of satisfaction and level of consumer purchase decisions.

\section{Customer Satisfaction}

According to Yazid in Kurniawan, et. al. (2020) customer satisfaction is those nothingness of difference between expectations they have with performance they actually received. Furthermore Kotler and Armstrong (2008) in Gunawan and Prasetyo (2020) said that customers set up those expectations regarding value and satisfaction that will be given from various market offers and buy accordance with that desires.

\section{Customer Loyalty}

According to Kotler and Keller in Tiasanty and Sitip (2019) loyalty is defined as strong commitment to buy or use certain products or services in future. Furthermore, Based on Griffin in Tiasanty and Sitip (2019) said that loyal customers would have characteristics of 
making repurchases regularly, buying between product / service lines, referring to others and having immunity of attraction over other products / services.

\section{Theoretical Framework}

Accordance to Theory result and background Matters Which has been mentioned above, these following framework could be made up as its follows:

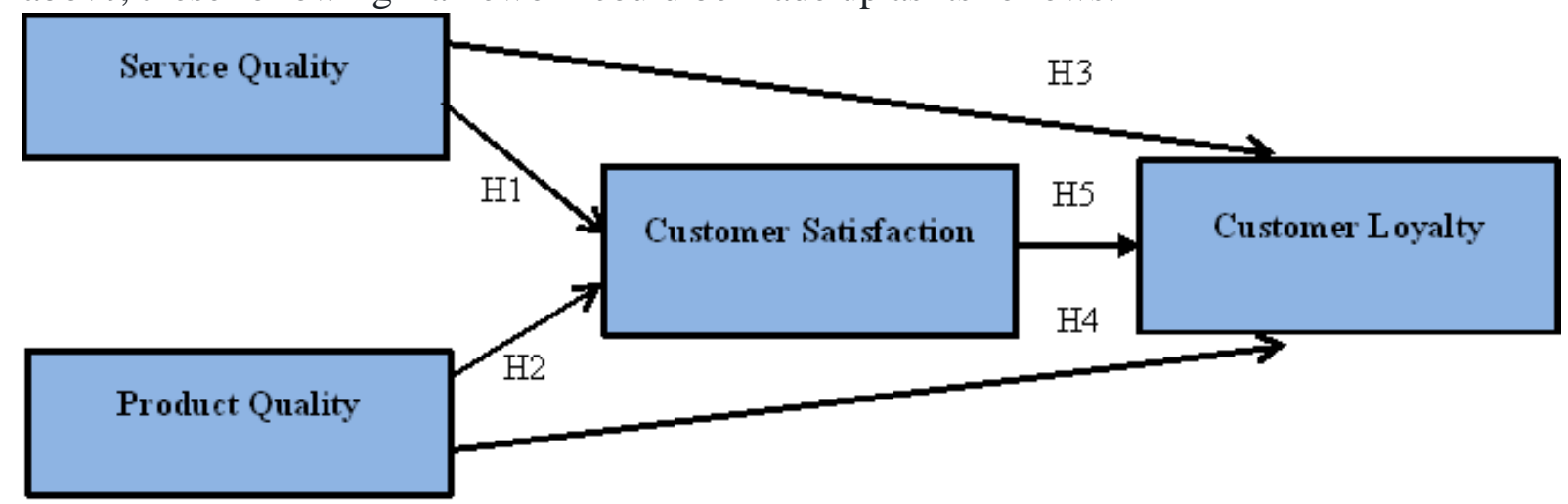

Figure 1. Theoretical Framework

\section{Hypothesis}

According to theoretical review, literature review, prior research outcome and theoretical framework there are several following hypothesis could be drawn by the authors for this research such as: 1) If customer satisfaction increases, so that service quality should be improved. 2) If customer satisfaction increased, so with product quality should be improved. 3) If customer loyalty increased, service quality should be improved. 4) If customer loyalty increased, so with product quality that should be improved. 5) If customer loyalty increased, these customer satisfaction should be increased too.

\section{METHODOLOGY}

This type of research used descriptive analytic research while Data was obtained by quantitative data which structured using a Likert scale 1-5. Independent variable in these research were consisted of service quality and promotion, the dependent variable was customer satisfaction which mediated by purchase decision variable. population here were customers of PT Cianjur Artha Makmur which total 543 customers based on company internal data in 2018. Those research sample was amounted to 100 respondents (Slovin 5\% error tolerance) taken from simple random sampling technique. Data analysis method in these research used the path analysis method with help of SPSS 23.0 program to test hypothesis.

\section{RESULTS AND DISCUSSIONS}

\section{Characteristics of Respondents}

Based on characteristics of these 100 respondents who are beef customers from PT Cianjur Artha Makmur, it could be described that majority of customers are male $(64.0 \%)$ aged between 31-40 years $(45.0 \%)$ who was graduated from Diploma (33.0\%) with has trading experience between 5-10 years (58.0\%). So it could be concluded that beef customers from PT Cianjur Artha Makmur are entrepreneurs who will enter retirement phase and who has trading experience and mature minds. 


\section{Validity and Reliability Test}

According to validity test, it is known that all these research indicators has $r$ count value > $\mathrm{r}$ table (0.196), so it could be stated that all indicators from these variables were declared valid.

Table 3. Validity Test Results

\begin{tabular}{|c|ccc|ccc|ccc|ccc|}
\hline Num. & $\mathrm{r}_{\text {count }} \mathrm{X}_{1}$ & $\mathrm{r}_{\text {table }}$ & Info & $\mathrm{r}_{\text {count }} \mathrm{X}_{2}$ & $\mathrm{r}_{\text {able }}$ & Info & $\mathrm{r}_{\text {count }} \mathrm{Y}$ & $\mathrm{r}_{\text {table }}$ & Info & $\mathrm{r}_{\text {count }} Z$ & $\mathrm{r}_{\text {tabla }}$ & Info \\
\hline 1 & 0.949 & 0.196 & Valid & 0.928 & 0.196 & Valid & 0.871 & 0.196 & Valid & 0.929 & 0.196 & Valid \\
2 & 0.972 & 0.196 & Valid & 0.953 & 0.196 & Valid & 0.884 & 0.196 & Valid & 0.936 & 0.196 & Valid \\
3 & 0.965 & 0.196 & Valid & 0.954 & 0.196 & Valid & 0,898 & 0.196 & Valid & 0.942 & 0.196 & Valid \\
4 & 0.970 & 0.196 & Valid & 0.931 & 0.196 & Valid & 0.830 & 0.196 & Valid & 0.954 & 0.196 & Valid \\
5 & & & & 0.954 & 0.196 & Valid & 0.870 & 0.196 & Valid & & & \\
\hline
\end{tabular}

Based on reliability test result, it is known that all variables which examined (service quality, product quality, price, customer satisfaction and customer loyalty) were reliable because all variables has Cronbanch's Alpha value $>0.60$

Table 4. Reliability Test Results

\begin{tabular}{lcc}
\hline \multicolumn{1}{c}{ Variable } & $\begin{array}{c}\text { Cronbanch's } \\
\text { Alpha }\end{array}$ & Information \\
\hline Service Quality & 0.853 & Reliable \\
Product Quality & 0.833 & Reliable \\
Customer Satisfaction & 0.821 & Reliable \\
Customer Loyalty & 0.849 & Reliable \\
\hline
\end{tabular}

\section{Classic Assumption Test}

Based on normality test results, it could be said that these data were normally distributed. It was because the Asymp value. Sig. (2-tailed) of .200 or greater than 0.05 .

Table 5. Normality Test Results One-Sample Kolmogorov-Smimov Test

\begin{tabular}{|c|c|c|}
\hline & & $\begin{array}{c}\text { Unstandardized } \\
\text { Residual } \\
\end{array}$ \\
\hline $\mathrm{N}$ & & 100 \\
\hline \multirow[t]{2}{*}{ Normal Parameters ${ }^{a, b}$} & Mean & .0000000 \\
\hline & Std. Deviation & 1.47998124 \\
\hline \multirow[t]{3}{*}{ Most Extreme Differences } & Absolute & .099 \\
\hline & Positive & 099 \\
\hline & Negative & -.087 \\
\hline Test Statistic & & 099 \\
\hline Asymp. Sig. (2-tailed) & & $619^{\circ}$ \\
\hline
\end{tabular}

According to multicollinearity test results, VIF value for service quality, product quality, and customer satisfaction variables is smaller than 10 . While the tolerance value is greater than 0.10. This shows that independent variables in these research do not correlate with each other or there is no correlation between these independent variables, so model does not contained multicollinearity. 
Table 6. Multicollinearity Test Results

\begin{tabular}{lccl}
\hline \multicolumn{1}{c}{ Variable } & Tolerance & VIF & Information \\
\hline Service Quality & 0,269 & 3,719 & There is no Multicollinearity \\
Product Quality & 0,204 & 8,607 & There is no Multicollinearity \\
Customer Satisfaction & 0,303 & 3,299 & There is no Multicollinearity \\
\hline
\end{tabular}

According to heteroscedasticity test result by scatterplot diagrams, it could be seen that the points spread randomly and spread both above and below the number 0 (zero) on $\mathrm{Y}$ axis. It could be said that there were no heteroscedasticity in these regression model.

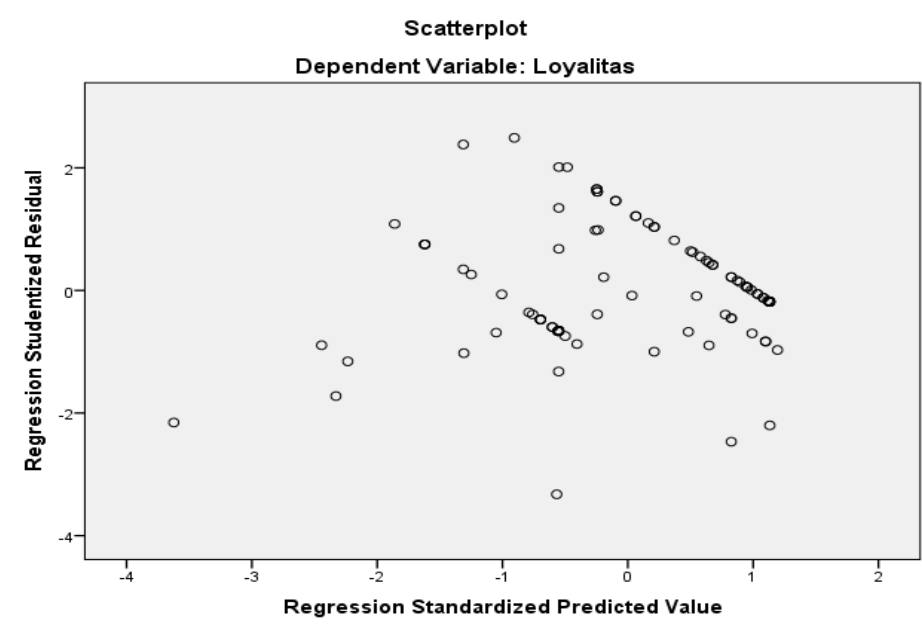

Figure 2. Heteroscedasticity Test Results

\section{Hypothesis Test}

Based on hypothesis test result, it is known that the $t$ count value on service quality variable is 2,424 >t table specified and Sig. $<0.05$, so it could be said that service quality has mutual and remarkable sign on customer satisfaction, $\mathrm{t}$ count value on product quality variable is $2.706>\mathrm{t}$ table specified and the Sig. $<0.05$, so it could be said that product quality has an mutual and strongly impact over customer satisfaction.

Table 7. Hypothesis 1 and 2 Test Results

\begin{tabular}{|c|c|c|c|c|c|c|}
\hline \multirow[b]{2}{*}{ Mod } & & \multicolumn{2}{|c|}{ Unstandardized Coefficients } & \multirow{2}{*}{$\begin{array}{c}\begin{array}{c}\text { Standardized } \\
\text { Coefficients }\end{array} \\
\text { Beta }\end{array}$} & \multirow[b]{2}{*}{$\mathrm{t}$} & \multirow[b]{2}{*}{ Sig. } \\
\hline & & $\mathrm{B}$ & Std. Error & & & \\
\hline \multirow[t]{3}{*}{1} & (Constant) & 6.703 & 1.081 & & 6.199 & .000 \\
\hline & Kualitas_Layanan & .302 & .100 & .315 & 2.424 & .006 \\
\hline & Kualitas_Produk & .364 & .134 & .455 & 2.706 & .008 \\
\hline
\end{tabular}

According to hypothesis test result, it is common that tcount value on service quality variable is $3.020>\mathrm{t}$ table specified and the Sig. $<0.05$, so it could be said that service quality has an beneficial huge impact against customer loyalty. T value on product quality variable is 3,719 > specified t table and the Sig. $<0.05$, so it could be stated that product quality has an strongly positive influence to customer loyalty. Tcount value on customer satisfaction variable is $6,440>\mathrm{t}$ table specified with value of Sig. $<0.05$, so it could be conclude that customer satisfaction has an positive remarkable affect towards customer loyalty. 
Table 8. Hypothesis 3, 4, and 5 Test Results

\begin{tabular}{|c|c|c|c|c|c|c|}
\hline \multirow[b]{2}{*}{ Mod } & & \multicolumn{2}{|c|}{ Unstandardized Coefficients } & \multirow{2}{*}{$\begin{array}{c}\begin{array}{c}\text { Standardized } \\
\text { Coefficients }\end{array} \\
\text { Beta }\end{array}$} & \multirow[b]{2}{*}{ t } & \multirow[b]{2}{*}{ Sig. } \\
\hline & & $\bar{B}$ & Std. Error & & & \\
\hline \multirow[t]{4}{*}{1} & (Constant) & 6.826 & 1.169 & & 7.272 & .000 \\
\hline & Kualitas_Layanan & .402 & .093 & .402 & 3.020 & .000 \\
\hline & Kualitas_Produk & .592 & .127 & .538 & 3.719 & .000 \\
\hline & Kepuasan_Pelanggan & .701 & .093 & .726 & 6.440 & .000 \\
\hline
\end{tabular}

The indirect effect of service quality and product quality on customer loyalty mediated by customer satisfaction has a greater value than its direct influence, so it can be concluded that customer satisfaction is able to perfectly mediate service quality and product quality on customer loyalty.

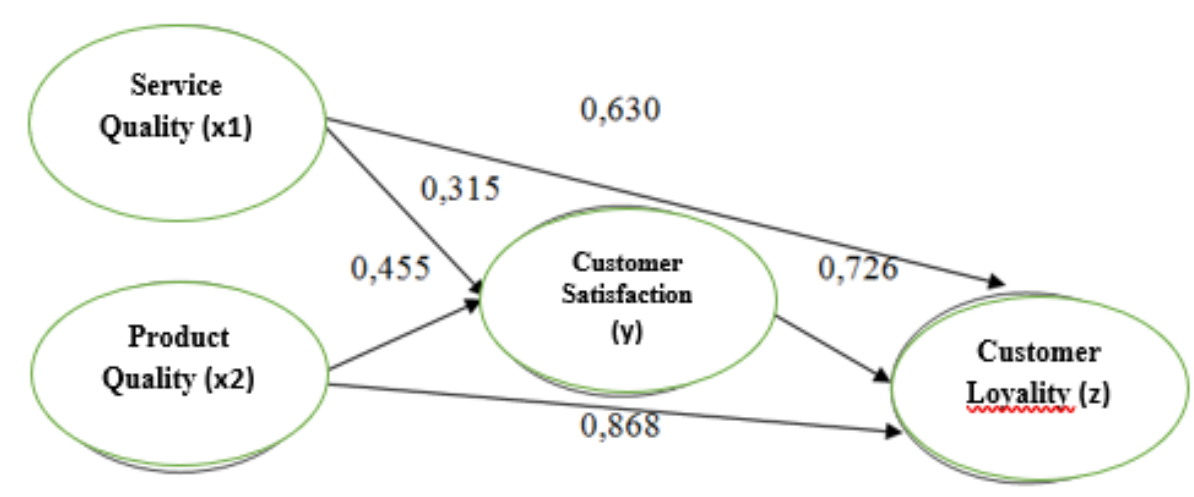

Figure 3. Path Analysis Diagram

\section{Correlation Between Dimensions}

The results of the correlation between dimensions in this study are as follows:

Table 9. Correlation Between Dimensions Results

\begin{tabular}{|c|c|c|c|c|c|c|c|c|c|c|}
\hline \multirow[b]{2}{*}{ Variable } & \multirow[b]{2}{*}{ Dimensi } & \multicolumn{5}{|c|}{ Customer Satisfaction (Y) } & \multicolumn{4}{|c|}{ Loyalitas Pelanggan (Z) } \\
\hline & & $\begin{array}{l}\text { Product } \\
\text { Quality } \\
\text { (Y1.1) }\end{array}$ & $\begin{array}{l}\text { Service } \\
\text { Quality } \\
\text { (Y1.2) }\end{array}$ & $\begin{array}{c}\text { Emotion } \\
(\mathrm{Y} 1.3)\end{array}$ & $\begin{array}{l}\text { Proce } \\
(\mathrm{Y} 1.4)\end{array}$ & Cost $(\mathrm{Y} 1.5)$ & $\begin{array}{l}\text { Reapeat } \\
\text { Buying } \\
\text { (Z1.1) }\end{array}$ & $\begin{array}{l}\text { Line } \\
\text { Purchase } \\
\text { (Z1.2) }\end{array}$ & $\begin{array}{l}\text { Give a } \\
\text { Reference } \\
\text { (Z1.3) }\end{array}$ & $\begin{array}{l}\text { Immunity of } \\
\text { Attraction } \\
\text { (Z1.4) }\end{array}$ \\
\hline \multirow{4}{*}{ Service Quality (X1) } & Design Quality (X1.1) &, $563^{* *}$ & $476^{* *}$ & $474^{* 8}$ & $367^{* *}$ &, $412^{* *}$ & $448^{* *}$ &, $366^{* *}$ &, $489 * *$ &, $486^{* *}$ \\
\hline & Production Quality (X1.2) &, $583^{* *}$ &, $501^{* *}$ &, $473 * 8$ &, $384^{* *}$ &, $401^{* *}$ &, $471^{* *}$ &, $372^{* *}$ &, $471^{* *}$ &, $487^{* *}$ \\
\hline & Delivery Quality (X1.3) &, $651^{* *}$ & $.553^{* *}$ &, $471^{* *}$ &, $383^{* *}$ & $415^{* *}$ & $463^{* *}$ &, $424^{* *}$ &, $425^{* *}$ & $460^{* *}$ \\
\hline & Relationship Qualtiy (X1.4) &, $659^{* *}$ &, $579^{* *}$ &, $520^{* *}$ & $433^{* *}$ &, $464^{* *}$ &, $532^{* *}$ & $.456^{* *}$ &, $494^{* *}$ &, $508^{* *}$ \\
\hline \multirow{5}{*}{ Product Quality (X2) } & Performance $(\mathrm{X} 2.1)$ &, $707^{* *}$ &, $633^{* *}$ &, $565^{* *}$ &, $444^{* *}$ &, $516^{* *}$ &, $535^{* *}$ & $500^{* *}$ &, $533^{* *}$ &, $547^{* *}$ \\
\hline & Feature (X2.2) &, $761^{* *}$ &, $701^{* *}$ &, $648^{* *}$ &, $512^{* *}$ &, $589 * *$ &, $654^{* *}$ &, $637^{* *}$ &, $632 * *$ &, $642^{* *}$ \\
\hline & Suitability (X2.3) &, $788^{* *}$ &, $717^{* *}$ &, $642^{* *}$ & $.528^{* *}$ &, $594^{* *}$ &, $613^{* *}$ &, $599 * *$ &, $591^{* *}$ &, $619^{* *}$ \\
\hline & Durability (X2.4) &, $804^{* *}$ &, $750^{* 8}$ &, $683^{* 8}$ &, $519^{* *}$ &, $585^{* 8}$ &, $581^{* *}$ &, $526^{* 8}$ &, $577^{* *}$ &, $590^{* *}$ \\
\hline & Reliability (X2.5) &, $811^{* *}$ &, $741^{* *}$ &, $684^{* *}$ &, $536 * *$ &, $596^{* *}$ &, $608^{* *}$ &, $596^{* *}$ &, $604^{* *}$ &, $616^{* *}$ \\
\hline \multirow{5}{*}{$\begin{array}{l}\text { Customer Satisfaction } \\
\text { (Y) }\end{array}$} & Product Quality (Y1.1) & & & & & &, $640^{* *}$ &, $631^{* *}$ &, $611^{* *}$ &, $626^{* *}$ \\
\hline & Service Quality (Y1.2) & & & & & &, $619^{* *}$ &, $608^{* *}$ &, $614^{* *}$ &, $649^{* *}$ \\
\hline & Emotion (Y1.3) & & & & & &, $671^{* *}$ &, $616^{* *}$ &, $615^{* *}$ &, $633^{* *}$ \\
\hline & Price (Y1.4) & & & & & &, $692^{* *}$ &, $613^{* *}$ &, $561^{* *}$ &, $605^{* *}$ \\
\hline & Cost (Y1.5) & & & & & &, $823^{* *}$ &, $773^{* *}$ &, $692^{* *}$ &, $729^{* *}$ \\
\hline
\end{tabular}


1) From these analysis of those relationship between dimensions above it could be said that dimensions from Service Quality variable to dimensions of Customer Satisfaction variable dimensions. These links between these dimensions has more dominant in Relationship Quality (X1.4) dimension to Product Quality (Y1.1) with a coefficient value of 0.659 that means it has strong relationship.

2) From these analysis of relationship between dimensions above, it could be said that dimensions from Product Quality variable to dimensions of Customer Satisfaction variable. The link between these dimensions is more dominant in Reliability dimension (X2.5) to Product Quality (Y1.1) with coefficient value of 0.811 which means it has very strong relationship.

3) From the analysis of the relationship between the dimensions above, it can be concluded that the dimensions of the Service Quality variable are the dimensions of the Customer Loyalty dimension. The relationship between these dimensions is more dominant in the Relationship Quality (X1.4) dimension to Repurchase (Z1.1) with a coefficient value of 0.532 , which means it has a moderate relationship.

4) From the analysis of the relationships between the dimensions above, it can be concluded that the dimensions of the Product Quality variable are the dimensions of the Customer Loyalty dimension. The relationship between these dimensions is more dominant found in the dimensions of Conformity (X2.3) to the Immunity of Attraction (Z1.4) with a coefficient value of 0.619 which means it has a strong relationship.

5) From the analysis of the relationships between the dimensions above, it can be concluded that the dimensions of the variable Customer Satisfaction of Customer Loyalty dimensions. The relationship between these dimensions is more dominant in the cost dimension (Y1.5) to Repurchase (Z1.1) with a coefficient value of 0.823 which means it has a very strong relationship.

\section{Discussion}

Based on research results, it is known that service quality has huge impact towards customer satisfaction. These results were in line with research that conducted by Gunawan and Prasetyo (2020)its showing that service quality has mutual and strongly influence over customer satisfaction. Quality provides an urges feeling to customers and established strong ties with company. In long run, this kind of bond would allows companies to carefully understand their expectations and needs so the company could increased customer satisfaction by maximizing pleasant on customer experiences and minimizing or eliminate unpleasant feeling over customer experiences.

Based on research results, it is known that product quality has an huge influence over customer satisfaction. The results has similiar with research that conducted by Rahman and Sitio (2019) it was shown that product quality has strong reacted over customer satisfaction. The product has an important meaning to company because without product, company won't be able to do anything witn its business. Consumers will buy product if they are interested and feel match with that, so the product should be adjusted to their wants or needs o so that the product marketing would get successful in those business. 
Based on research results, it is known that service quality has huge impact to customer loyalty. These results were in line with research that conducted by Tiasanty and Sitio (2019) showing that service quality has beneficial and remarkable reaction against customer loyalty. Companies need to improve competitiveness starting from on-time delivery and pricing policies because of these two things are considered by customers in using overland shipping services. To convince customers in using facilities and landline services is not easy, one way is to maximized customer loyalty behavior. The use of customer loyalty would caused by long-term effects of loyalty itself, with hope that customers will continue to use the services from shipping company continuously and repeatedly. Service quality would also become major factor which affecting customer loyalty because customers who are satisfied with their personal values and experience would give a good impact over service will have high loyalty to company.

According to results, it is known that product quality has an huge impact towards customer loyalty. These results were in line with research that conducted by Tiasanty and Sitio (2019) which shows that product quality has positive and strong influence towards customer loyalty. Product quality is an important factor influencing customer satisfaction. Product quality is determined factor for customer satisfaction after making a purchase and use of a product. Product quality is a form of complex satisfaction value. By a good quality of product, the desires and needs of consumers for product will be fulfilled. If these quality of product received is higher than expected, the perceived quality of product will be satisfactory.

Based on those results, it is known that customer satisfaction has huge impact towards customer loyalty. Research which conducted by Tiasanty and Sitio (2019) shows that customer satisfaction has positive and huge influence towards customer loyalty. The creation of an optimal level for customer satisfaction would encourages those creation on loyalty in minds of satisfied customers. Customer loyalty has seen as strength relationship between someone's relative attitude and its repeat business.

\section{CONCLUSION AND SUGGESTION Conclusion}

According to result from research that has been conducted, there are several conclusions that could be drawn from here such as:

1) Research outcome showed that Service Quality has an huge impact towards Customer Satisfaction. The high dominant of dimension which found in Relationship Quality dimension (X1.4) with coefficient value of 0.659 it means it has a strong relationship.

2) Research outcome has shown that Product Quality has an strong Influence against Customer Satisfaction. The highest dominant dimension has found in Reliability dimension (X2.5) with coefficient value of 0.811 that means it has very strong relationship.

3) Research outcome Tells that Service Quality has an huge reacted over Customer Loyalty. The more dominant dimension was found in Relationship Quality dimension (X1.4) with coefficient value of 0.532 , that means it has a moderate relationship.

4) Research results showed that Product Quality has an significant Reaction on Customer Loyalty. The more dominant dimension Was found in Conformity dimension (X2.3) with coefficient value of 0.619 that means it has a strong relationship. 
5) The results showed that Customer Satisfaction significantly has an influenced to Customer Loyalty. The more dominant dimension could be found in Cost dimension (Y1.5) with a coefficient value of 0.823 that means it has very strong relationship.

\section{Suggestion}

According to these results of conclusions, these following suggestions Could be made from this research such as in belows:

1) Based on these research, it is known that the Cost Dimension (Y1.5) has a greater correlation value than the other dimensions on Customer Loyalty. Therefore, it is recommended for PT.CAM to put better pricing so that it could reach all buyers without eliminating those quality of meat. By cost satisfaction to be incurred by the customer it will create repurchases thereby increasing income of PT. CAM as a whole in long run.

2) It is suggests for further research to add other variables to examined those effect on customer satisfaction and customer loyalty.

\section{REFERENCES}

Agbor, Jenet. M.(2011). The Relationship Between Customer Satisfaction and Service Quality: A Study of Three Service Sectors in Umea. Thesis, Umea School of Business. America.

Daryanto, Arief. (2010). Poultry Industry Outlook. Direktur Program Pascasarjana.

Desyana dan Har Adi Basri. (2019). The Influence of Brand Image, Product Quality, Brand Awareness on Satisfaction and the Impact on Customer's Loyalty of PT. Altindo Mulia. International Journal of Innovative Science and Research Technology, 4(8).

Gunawan, Hendrik dan Johan Hendri Prasetyo. (2020). The Influence of Service Quality towards the Customer Satisfaction of XYZ Bank at Gajah Mada Branch Office in West Jakarta. International Journal of Innovative Science and Research Technology, Vol. 5, Issue 3.

Kurniawan, Muchammad Rizal, Halimah Rachmawati Utami, dan Johan Hendi Prasetyo. (2020). The reaction towards Customer Satisfaction through the Service Quality Variable at Foreign Private Banks in Jakarta Headquarter. International Journal of Innovative Science and Research Technology, Vol. 5, Issue 3.

Pradita, Syvia Okta dan Arifin Sitio. (2020). The Impact of Brand Image and Service Quality on Buying Decisions and Its Implication on Consumer Satisfaction (Case Study at PT IMI). Dinasti International Journal of Digital Business Management, 1(3).

Prianggoro, Noro Fajar dan Arifin Sitio. (2019). Effect of Service Quality and Promotion on Purchase Decisions and Their Implications on Customer Satisfaction. International Journal of Engineering Technologies and Management Research, 6(1).

Rahman, Haikal Aulia dan Arifin Sitio. (2019). The Effect of Promotion and Product Quality Through Purchase Decision on The Customer Satisfaction Of Bohemian Project.id Products. International Journal of Engineering Technologies and Management Research, 6(1).

Tiasanty, Lise dan Arifin Sitio. (2019). Analysis of the Effect of Service Quality, Product Quality and Brand Image on Customer Satisfaction and Its Implications on 
Consumer Loyalty PT. Sharp Electronics Indonesia (Case Study at Karawang Sharp Direct Service Station). International Journal of Engineering Technologies and Management Research, 6(1). 